\title{
Smoking and the risk of COVID-19 in a large observational population study
}

Ariel Israel, $\mathrm{MD}, \mathrm{PhD}$

Elan Feldhamer, BA

Amnon Lahad, MD, MPH

Diane Levin-Zamir, PhD, MPH, MCHES

Gil Lavie, MD, MHA, MBA

\section{Authors Affiliations:}

Division of Planning and Strategy, Clalit Health Services, Israel (Israel, Feldhamer, Lavie); Ruth and Bruce Rappaport Faculty of Medicine, Technion-Israel Institute of Technology, Haifa, Israel (Lavie); Departments of Family Medicine, Clalit Health Services and Hebrew University, Jerusalem, Israel (Lahad); Department of Health Education and Promotion, Clalit Health Services; University of Haifa School of Public Health, Israel (Levin-Zamir)

\section{Corresponding Author:}

Ariel Israel, MD, PhD

Department of Research and Data

Division of Planning and Strategy

Clalit Health Services

101 Arlozorov Street

Tel Aviv 62098, Israel

Telephone: +972-3-6948160

Email: dr.ariel.israel@gmail.com 


\section{Smoking and the risk of COVID-19 in a large observational population study}

\section{Abstract: \\ BACKGROUND}

Smokers are generally more susceptible to infectious respiratory diseases and are at higher risk of developing severe complications from these infections. Conflicting reports exist regarding the impact of smoking on the risk of Coronavirus disease 2019 (COVID-19).

\section{METHODS}

We carried out a population-based study among over $3,000,000$ adult members of Clalit Health Services, the largest health provider in Israel. Since the beginning of the disease outbreak, and until May 16, 2020, over 145,000 adults underwent RT-PCR testing for Severe Acute Respiratory Syndrome Coronavirus 2 (SARS-CoV-2), and 3.3\% had positive results. We performed a casecontrol study among patients who underwent SARS-CoV-2 testing, to assess the impact of smoking on infection incidence and severity. Individuals with positive tests were matched in a 1:5 ratio to individuals tested negative, of the same sex, age, and ethnicity/religion. Conditional logistic regressions were performed to evaluate odds ratios for current and previous smoking on the risk of testing positive. Multivariable logistic regressions were performed among patients infected with COVID-19 to estimate the association between smoking and fatal or severe disease requiring ventilation. Regressions were performed with and without adjustment for preexisting medical conditions.

\section{RESULTS}

Current smokers (9.8\%) were significantly less prevalent among members tested positive compared to the general population $(19.4 \%, \mathrm{P}<0.001)$, and to matched members tested negative (18.2\%, $P<0.001)$. Current smoking was associated with significantly reduced odds ratio (OR) for testing positive $\mathrm{OR}=0.447$ (95\% confidence interval $(\mathrm{Cl})$ 0.400-0.501). Among patients tested positive, there was no evidence of significantly increased risk of developing severe or fatal disease.

\section{CONCLUSION}

The risk of infection by COVID-19 appears to be reduced by half among current smokers. This intriguing finding may reveal unique infection mechanisms present for COVID-19 which may be targeted to combat the disease and reduce its infection rate. 
medRxiv preprint doi: https://doi.org/10.1101/2020.06.01.20118877; this version posted June 5, 2020. The copyright holder for this preprint

(which was not certified by peer review) is the author/funder, who has granted medRxiv a license to display the preprint in perpetuity.

All rights reserved. No reuse allowed without permission.

SARS-Cov-2 is a new virus, which was first identified in December 2019, and has rapidly spread into a global pandemic of primarily respiratory illness designated as Coronavirus Disease 2019 (COVID-19). This disease is associated with significant mortality, particularly among the aging population, raising considerable concerns for public health. Smokers are at greater risk for respiratory infections and were expected to be at increased risk for Covid-19 as well ${ }^{1-3}$. Nevertheless, some reports appear to indicate that SARS-Cov-2 infection rate is not higher among smokers, and in several cohorts, the infection rate among smokers was lower than in the general population ${ }^{4-7}$. There are also conflicting data regarding clinical outcomes for smokers, and whether smoking is a risk factor for more severe disease. A recent review published by the World Health Organization summarizes the conflicting results of the studies available to date, and the lack of knowledge regarding the association between smoking and the risk of SARS-CoV-2 infection and disease severity ${ }^{8}$, highlighting the need for population-based studies to better understand the association. We report here the results of a large population study performed among adult members of Clalit Health Services (CHS), the largest healthcare provider in Israel.

\section{Methods}

\section{Study population and data collection}

Clalit Health Services (CHS) provides comprehensive health services to over 3,000,000 adult members, and centrally manages electronic health records (EHR) including longitudinal records for over two decades. We anonymously collected selected variables from the EHR of patients who underwent SARS-Cov-2 testing and had documented smoking status. Demographic variables, including age, gender, religious/ethnic group, were collected from the CHS database. Preexisting conditions were considered present when a corresponding documented diagnosis was present in the EHR. Patients were considered obese if their last documented body mass index (BMI) was above 30, or if they had a documented diagnosis of obesity. Follow-up, including hospitalization, condition severity, the need for ventilation, and mortality were extracted from hospitalization records collected by the Israeli Ministry of Health, up to June 3, 2020.

CHS institutional review board approved the project with a waiver of informed consent, approval number: COM-0046-20.

\section{Statistical analysis}


medRxiv preprint doi: https://doi.org/10.1101/2020.06.01.20118877; this version posted June 5, 2020. The copyright holder for this preprint

(which was not certified by peer review) is the author/funder, who has granted medRxiv a license to display the preprint in perpetuity.

All rights reserved. No reuse allowed without permission.

We identified adult patients, who underwent RT-PCR testing for SARS-CoV-2 until the cut-off date of May 16, 2020, and who aged, at the time of the test between 18 and 95 years. Within this population, we defined a matched cohort where each patient positive for SARS-CoV-2 was matched to five patients tested negative of the same gender, age group (in five years intervals), and religious/ethnic group. Conditional logistic-regression models were fitted for estimating the oddsratio (OR) and corresponding $95 \%$ confidence interval $(\mathrm{Cl})$ for the risk of testing positive. A separate model, accounting for preexisting conditions, including chronic obstructive pulmonary disease (COPD), asthma, hypertension, obesity, reported arrhythmia, peripheral vascular disease, ischemic heart disease, and malignancy, was fitted to account for conditions potentially influencing the risk associated to smoking.

Among patients tested positive, we assessed the effect of smoking status on the risk of fatal or severe disease requiring mechanical ventilation, by fitting multivariable logistic models accounting for gender, age category, and religious/ethnic groups. A separate model was also performed to adjust for preexisting conditions.

Statistical significance of differences observed between groups was assessed by the Chi-Square test for categorical variables, and two tailed T-test for continuous variables. P-values below 0.05 were considered significant. Statistical analyses were performed using R statistical software version 3.6 ( $R$ Foundation for statistical computing).

\section{Results}

The flowchart of the cohort creation is presented as Figure 1. From the beginning of the outbreak and until May 16, 2020, 128,427 distinct CHS members with documented smoking status, underwent RT-PCR tests for SARS-CoV-2, 4,235 (3.3\%) of whom tested positive. Among them, we found that $9.8 \%$ were current smokers and $11.7 \%$ past smokers, while their corresponding rates within the adult population of CHS were $19.4 \%$ and $13.9 \%$ respectively $(\mathrm{P}<0.001)$.

The characteristics of the matched cohort are shown in Table 1. The observed difference in smoking status is maintained in this cohort: current smoking prevalence is significantly lower among patients who tested positive (9.8\%) than among matched patients tested negative (18.2\%). Table 2 presents the regression results for testing positive for COVID-19 in the matched cohort. In column A, the results of the conditional logistic regression are presented, adjusted only for age, gender, and religion/ethnicity categories. In this model, current smoking was associated with significantly reduced $\mathrm{OR} 0.447$, with a $95 \% \mathrm{Cl}$ of $0.400-0.501$. Interestingly, odds for testing positive were also 
medRxiv preprint doi: https://doi.org/10.1101/2020.06.01.20118877; this version posted June 5, 2020. The copyright holder for this preprint

(which was not certified by peer review) is the author/funder, who has granted medRxiv a license to display the preprint in perpetuity.

All rights reserved. No reuse allowed without permission.

significantly reduced in past smokers, although the effect was more moderate: OR $0.757(95 \% \mathrm{Cl}$ 0.679-0.844). We assessed these associations in a separate model adjusted for preexisting conditions and found very similar results for smoking (column B). Interestingly, odds for positive testing was increased for obese patients OR 1.172 (95\% Cl 1.084-1.267) but decreased in hypertensive patients OR 0.834 ( $95 \% \mathrm{Cl} 0.738-0.941)$, suggesting that among these two frequently correlated conditions, obesity is the one associated with increased infection rate. Odds ratio for infection were also decreased for patients with asthma or malignancy, likely reflecting increased adherence to social distancing recommendations among these patients.

Table 3 describes the odds ratio for the risk of severe or fatal disease among patients positive for SARS-CoV-2 in the cohort. Severe or fatal disease was very strongly associated with increasing age and with male gender, as evidenced by most studies to date. However, we found no statistically significant association between current or past smoking and disease severity, both in the model adjusted for baseline demographic characteristics (model A, adjusted for age, gender, and religious/ethnic group), and in the model that accounted for preexisting conditions as well (model B); in the latter model, presence of ischemic heart disease or malignancy was associated with significantly increased odds ratio for severe or fatal disease.

\section{Discussion}

In this large population of patients tested for COVID-19 infection, there appears to be significantly reduced risk for COVID-19 infection among smokers, in contrast to what occurs in most respiratory infections. This intriguing observation confirms several recently published studies, that also reported decreased disease incidence among smokers ${ }^{4,6,7,9}$, although in a smaller scale. Interestingly, even among SARS-CoV-2 positive patients, we found no evidence of significant association between current or past smoking and disease severity, as reflected by death during hospitalization or by need for mechanical ventilation.

To our knowledge, this is the first study to assess the association between smoking and COVID-19 infection in a matched cohort of this scale. The magnitude of association observed for current smoking, with odds of infection reduced by about a half in smokers, suggests a genuine protective effect of smoking on the risk of COVID-19. A significant negative association is also observed between past smoking and SARS-CoV-2 infection, although more moderate than the one observed for current smoking. It is unclear whether the latter association reflects long-term changes engendered by past smoking, or unreported smoking recidivism among these patients. Among 
medRxiv preprint doi: https://doi.org/10.1101/2020.06.01.20118877; this version posted June 5, 2020. The copyright holder for this preprint

(which was not certified by peer review) is the author/funder, who has granted medRxiv a license to display the preprint in perpetuity.

All rights reserved. No reuse allowed without permission.

infected patients, we did not observe a significant association between current smoking and severity of disease, in contrast to what occurs in most respiratory infections. Other national cohorts did not observe an increased risk for severe disease among smokers as well, while some smaller studies sampling hospitalized patients observed increased risk among smokers ${ }^{1,2,10}$. These apparently conflicting results may reflect different thresholds for patient inclusion. Our cohort included many patients who were asymptomatic or had light symptoms and did not undergo hospitalization. It is possible that among study samples based on patients hospitalized for serious disease, smoking or past smoking contributes to disease aggravation. Future studies should examine more in-depth specific smoking habits, for example light to heavy smoking, to discern whether there is a possible dose response, or whether the possible protective effect is based on a specific threshold.

The negative association observed here between smoking and COVID-19 infection incidence is uncommon among respiratory infections, and possibly reflects unique infection mechanisms present in the novel coronavirus. Changeux et $\mathrm{al}^{11}$, relying on similar observations, propose a crucial role for the nicotinic acetylcholine receptor (nAChR) in COVID-19 pathology. According to their neurotropic hypothesis, SARS-CoV-2 invades the central nervous system through the $\mathrm{nAChR}$ receptor, present in neurons of the olfactory system, as reflected by the frequent occurrence of neurologic symptoms, such as loss of smell or taste, or intense fatigue in patients affected by COVID-19. Other mechanisms may also affect SARS-CoV-2 infection potential in smokers. It is widely accepted that the angiotensin converting enzyme 2 (ACE2) represents the main receptor molecule for SARS-CoV-2, and smoking has been shown to differentially affect ACE2 expression in tissues ${ }^{12-14}$. Other putative explanations could involve altered cytokine expression such as IL-6, for which increased levels are associated with unfavorable disease outcome $\mathrm{e}^{14,15}$.

The effect of smoking among the study population was assessed through self-reported information routinely collected during medical visits, prior to occurrence of COVID-19, thus eliminating possible recall bias by patients. The matched cohort design, and the decision to only include patients that have been tested for SARS-CoV-2, overcomes the potential confounding effects of age, gender, and ethnicity/religious group, on smoking habits. We acknowledge our study's limitations as observational, noting the difficulty in eliminating all possible confounders. However, in the context of a harmful and addictive habit such as smoking, a controlled trial is not ethical.

Acknowledging the destructive effects of smoking on health, the importance of smoking prevention and cessation to preserve health, and the highly addictive nature of nicotine, we strongly encourage all patients to refrain from smoking, as the long term effects of this hazardous habit far outweigh potential benefits in preventing SARS-CoV-2 infection. Nevertheless, the strong negative association 
medRxiv preprint doi: https://doi.org/10.1101/2020.06.01.20118877; this version posted June 5, 2020. The copyright holder for this preprint (which was not certified by peer review) is the author/funder, who has granted medRxiv a license to display the preprint in perpetuity. All rights reserved. No reuse allowed without permission.

demonstrated in this study between smoking and COVID-19 incidence may offer promising new directions for fighting this disease, based on a better understanding of the mechanisms by which smoking reduces the risk of SARS-CoV-2 infection.

\section{Acknowledgement:}

All authors have no conflict of interest to report

No external funding was received for this study 
medRxiv preprint doi: https://doi.org/10.1101/2020.06.01.20118877; this version posted June 5, 2020. The copyright holder for this preprint (which was not certified by peer review) is the author/funder, who has granted medRxiv a license to display the preprint in perpetuity.

All rights reserved. No reuse allowed without permission.

1. Emami A, Javanmardi F, Pirbonyeh N, Akbari A. Prevalence of Underlying Diseases in Hospitalized Patients with COVID-19: a Systematic Review and Meta-Analysis. Arch Acad Emerg Med. 2020;8(1):e35. Accessed May 8, 2020.

http://www.ncbi.nlm.nih.gov/pubmed/32232218

2. Zhao Q, Meng M, Kumar R, et al. The impact of COPD and smoking history on the severity of Covid-19: A systemic review and meta-analysis. J Med Virol. Published online April 15, 2020. doi:10.1002/jmv.25889

3. Lawrence H, Hunter A, Murray R, Lim WS, McKeever T. Cigarette smoking and the occurrence of influenza - Systematic review. J Infect. 2019;79(5):401-406.

doi:10.1016/j.jinf.2019.08.014

4. Yanover C, Mizrahi B, Kalkstein N, et al. What factors increase the risk of complications in SARS-CoV-2 positive patients? A cohort study in a nationwide Israeli health organization. medRxiv. Published online May 13, 2020:2020.05.07.20091652.

doi:10.1101/2020.05.07.20091652

5. OpenSAFELY Collaborative T, Williamson E, Walker AJ, et al. OpenSAFELY: factors associated with COVID-19-related hospital death in the linked electronic health records of 17 million adult NHS patients. doi:10.1101/2020.05.06.20092999

6. Miyara M, Tubach F, POURCHER V, et al. Low incidence of daily active tobacco smoking in patients with symptomatic COVID-19. Qeios. Published online April 21, 2020.

doi:10.32388/wpp19w.3

7. Lippi G, Henry BM. Active smoking is not associated with severity of coronavirus disease 2019 (COVID-19). Eur J Intern Med. 2020;75:107-108. doi:10.1016/j.ejim.2020.03.014

8. Organization WH. Smoking and COVID-19. Published online 2020:19. Accessed May 30, 2020. https://www.who.int/publications-detail/smoking-and-covid-19

9. OpenSAFELY Collaborative T, Williamson E, Walker AJ, et al. OpenSAFELY: factors associated with COVID-19-related hospital death in the linked electronic health records of 17 million adult NHS patients. doi:10.1101/2020.05.06.20092999

10. Mehra MR, Desai SS, Kuy S, Henry TD, Patel AN. Cardiovascular Disease, Drug Therapy, and Mortality in Covid-19. N Engl J Med. Published online May 1, 2020:NEJMoa2007621. doi:10.1056/NEJMoa2007621

11. CHANGEUX jean-pierre, Amoura Z, Rey F, Miyara M. A nicotinic hypothesis for Covid-19 with preventive and therapeutic implications. Qeios. Published online April 22, 2020. doi:10.32388/fxgqsb.2

12. Fedson DS, Opal SM, Rordam OM. Hiding in plain sight: An approach to treating patients with severe covid-19 infection. MBio. 2020;11(2). doi:10.1128/mBio.00398-20

13. Olds JL, Kabbani N. Is nicotine exposure linked to cardiopulmonary vulnerability to COVID19 in the general population? FEBS J. Published online March 28, 2020. 
medRxiv preprint doi: https://doi.org/10.1101/2020.06.01.20118877; this version posted June 5, 2020. The copyright holder for this preprint (which was not certified by peer review) is the author/funder, who has granted medRxiv a license to display the preprint in perpetuity. All rights reserved. No reuse allowed without permission.

doi:10.1111/febs.15303

14. Brake SJ, Barnsley K, Lu W, McAlinden KD, Eapen MS, Sohal SS. Smoking Upregulates Angiotensin-Converting Enzyme-2 Receptor: A Potential Adhesion Site for Novel Coronavirus SARS-CoV-2 (Covid-19). J Clin Med. 2020;9(3):841. doi:10.3390/jcm9030841

15. Ulhaq ZS, Soraya GV. Interleukin-6 as a potential biomarker of COVID-19 progression. Med Mal Infect. Published online 2020. doi:10.1016/j.medmal.2020.04.002 
medRxiv preprint doi: https://doi.org/10.1101/2020.06.01.20118877; this version posted June 5, 2020. The copyright holder for this preprint (which was not certified by peer review) is the author/funder, who has granted medRxiv a license to display the preprint in perpetuity.

Table 1: Demographics and Clinical characteristics of the matched cohort of patients who tested positive and negative for COVID-19

\begin{tabular}{|c|c|c|}
\hline & $\begin{array}{l}\text { COVID-19 Positive } \\
\text { (Cases) }\end{array}$ & $\begin{array}{l}\text { COVID-19 Negative } \\
\text { (Controls) }\end{array}$ \\
\hline $\mathrm{N}$ & 4,151 & 20,755 \\
\hline Age (median [IQR]) & $39.54[27.38,58.26]$ & $39.65[27.55,58.67]$ \\
\hline Gender female (\%) & $1998(48.1)$ & $9990(48.1)$ \\
\hline \multicolumn{3}{|l|}{ Smoking status (\%) } \\
\hline never smoker & $3,262(78.5)$ & $14,301(68.9)$ \\
\hline current smoker & $406(9.8)$ & $3,783(18.2)$ \\
\hline past smoker & $483(11.6)$ & $2,671(12.9)$ \\
\hline \multicolumn{3}{|l|}{ Ethnicity/Religion (\%) } \\
\hline Jewish/General & $2,466(59.4)$ & $12,330(59.4)$ \\
\hline Arab & $672(16.2)$ & $3,360(16.2)$ \\
\hline Jewish Orthodox & $1,013(24.4)$ & $5,065(24.4)$ \\
\hline \multicolumn{3}{|l|}{ Age group (\%) } \\
\hline $18-34$ & $1,748(42.1)$ & $8,740(42.1)$ \\
\hline $35-54$ & $1,161(28.0)$ & $5,805(28.0)$ \\
\hline $55-74$ & $998(24.0)$ & $4,990(24.0)$ \\
\hline $75-$ & $244(5.9)$ & $1,220(5.9)$ \\
\hline Body Mass Index (BMI) (mean (SD)) & $27.35(5.74)$ & $26.99(5.73)$ \\
\hline \multicolumn{3}{|l|}{ BMI group (\%) } \\
\hline$<20$ & $211(5.1)$ & $1,216(5.9)$ \\
\hline $20-25$ & $997(24.0)$ & $5,331(25.7)$ \\
\hline $25-30$ & $1,031(24.8)$ & $5,322(25.6)$ \\
\hline $30-$ & 909 (21.9) & 4,059 (19.6) \\
\hline missing BMI & $1,003(24.2)$ & $4,827(23.3)$ \\
\hline $\begin{array}{l}\text { Number of visits to primary doctor (mean (SD)) in } \\
\text { the last year }\end{array}$ & $4.88(5.37)$ & $5.46(6.43)$ \\
\hline \multicolumn{3}{|l|}{ Chronic conditions: } \\
\hline Chronic obstructive pulmonary disease (COPD) & $80(1.9)$ & $599(2.9)$ \\
\hline Asthma & $195(4.7)$ & $1286(6.2)$ \\
\hline Hypertension & $655(15.8)$ & $3,599(17.3)$ \\
\hline Obesity* & $1269(30.6)$ & $5,895(28.4)$ \\
\hline Peripheral vascular disease & $50(1.2)$ & $353(1.7)$ \\
\hline Ischemic Heart Disease & $236(5.7)$ & $1,371(6.6)$ \\
\hline Malignancy & $231(5.6)$ & $1,438(6.9)$ \\
\hline \multicolumn{3}{|l|}{ COVID-19 hospitalization status (\%) ${ }^{1}$} \\
\hline hospitalized in good condition & $623(15.0)$ & \\
\hline hospitalized in moderate condition & $166(4.0)$ & \\
\hline hospitalized in severe condition & $85(2.0)$ & \\
\hline deceased & $75(1.8)$ & \\
\hline
\end{tabular}

IQR: Interquartile range

* In this and other tables, obesity is defined as presence of obesity diagnosis in the electronic medical record or last measured body mass index (BMI) above $30 .{ }^{1}$ Worst condition of the patient 
medRxiv preprint doi: https://doi.org/10.1101/2020.06.01.20118877; this version posted June 5, 2020. The copyright holder for this preprint (which was not certified by peer review) is the author/funder, who has granted medRxiv a license to display the preprint in perpetuity. All rights reserved. No reuse allowed without permission.

during hospitalization: patients who deceased were not counted as hospitalized in good, moderate or severe condition.

Table 2: Conditional logistic regression for estimating smoking and comorbidity effects on SARSCoV-2 infection status in the matched cohort $(N=24,906$; positive outcome: 4,151 who had positive test)

\begin{tabular}{|l|c|c|c|c|c|c|}
\hline & \multicolumn{3}{|c|}{ (A) Conditional } & \multicolumn{2}{c|}{ (B) Adjusted for comorbidity } \\
\hline & OR & Cl (95\%) & p-value & OR & Cl (95\%) & p-value \\
\hline Smoking status: & & & & & & \\
\hline never smoker & & reference & & & reference & \\
\hline current smoker & 0.447 & $0.400-0.501$ & $<0.001$ & 0.453 & $0.405-0.507$ & $<0.001$ \\
\hline past smoker & 0.757 & $0.679-0.844$ & $<0.001$ & 0.773 & $0.693-0.863$ & $<0.001$ \\
\hline & & & & & & \\
\hline Chronic conditions: & & & & & & \\
\hline $\begin{array}{l}\text { Chronic obstructive } \\
\text { pulmonary disease } \\
\text { (COPD) }\end{array}$ & & & & 0.880 & $0.687-1.128$ & 0.314 \\
\hline Asthma & & & & 0.766 & $0.654-0.896$ & 0.001 \\
\hline Hypertension & & & & 0.834 & $0.738-0.941$ & 0.003 \\
\hline Obesity & & & & 1.172 & $1.084-1.267$ & $<0.001$ \\
\hline Arrhythmia & & & & 0.906 & $0.756-1.085$ & 0.285 \\
\hline $\begin{array}{l}\text { Peripheral vascular } \\
\text { disease }\end{array}$ & & & & 0.839 & $0.615-1.146$ & 0.271 \\
\hline Ischemic Heart Disease & & & & 0.936 & $0.791-1.108$ & 0.445 \\
\hline Malignancy & & & & 0.788 & $0.677-0.917$ & 0.002 \\
\hline
\end{tabular}

Model $(A)$ is based on a conditional logistic regression adjusted for age, gender and ethnicity/religion strata. Model (B) is based on multivariable logistic regression accounting for age, gender and ethnicity strata, and the assessed chronic conditions (COPD, asthma, hypertension, obesity, reported arrhythmia, peripheral vascular disease, ischemic heart disease, and malignancy) 
medRxiv preprint doi: https://doi.org/10.1101/2020.06.01.20118877; this version posted June 5, 2020. The copyright holder for this preprint (which was not certified by peer review) is the author/funder, who has granted medRxiv a license to display the preprint in perpetuity.

All rights reserved. No reuse allowed without permission.

Table 3: Logistic regression for estimating smoking, demographic and comorbidity effects on fatal or severe disease among SARS-CoV-2 positive $(N=4,151$; positive outcome: 160 who had severe or fatal disease)

\begin{tabular}{|c|c|c|c|c|c|c|}
\hline & \multicolumn{3}{|c|}{$\begin{array}{l}\text { (A) Adjusted for age, sex, and } \\
\text { ethnic/religious sector }\end{array}$} & \multicolumn{3}{|c|}{ (B) Adjusted for comorbidity } \\
\hline & OR & $\mathrm{Cl}(95 \%)$ & $\mathrm{p}$-value & OR & $\mathrm{Cl}(95 \%)$ & $p$-value \\
\hline \multicolumn{7}{|l|}{ Smoking status: } \\
\hline never smoker & & reference & & & reference & \\
\hline current smoker & 0.618 & $0.289-1.323$ & 0.215 & 0.586 & $0.265-1.296$ & 0.187 \\
\hline past smoker & 1.347 & $0.903-2.010$ & 0.144 & 1.108 & $0.729-1.687$ & 0.631 \\
\hline Gender female & 0.620 & $0.435-0.883$ & 0.008 & 0.644 & $0.444-0.933$ & 0.020 \\
\hline \multicolumn{7}{|l|}{ Age group: } \\
\hline $18-34$ & & reference & & & reference & \\
\hline $35-54$ & 3.486 & $1.334-9.114$ & 0.011 & 3.118 & $1.189-8.178$ & 0.021 \\
\hline $55-74$ & 23.873 & $10.275-55.468$ & $<0.001$ & 14.992 & $6.253-35.944$ & $<0.001$ \\
\hline $75+$ & 90.593 & $38.102-215.399$ & $<0.001$ & 39.321 & $15.414-100.311$ & $<0.001$ \\
\hline \multicolumn{7}{|l|}{ Ethnic/religious sector: } \\
\hline General (Jewish) & & reference & & & reference & \\
\hline Arab & 0.970 & $0.535-1.758$ & 0.920 & 0.926 & $0.502-1.708$ & 0.805 \\
\hline Jewish Orthodox & 0.999 & $0.656-1.522$ & 0.997 & 1.111 & $0.722-1.710$ & 0.631 \\
\hline \multicolumn{7}{|l|}{ Chronic conditions: } \\
\hline $\begin{array}{l}\text { Chronic obstructive } \\
\text { pulmonary disease } \\
\text { (COPD) }\end{array}$ & & & & 0.987 & $0.485-2.011$ & 0.972 \\
\hline Asthma & & & & 0.986 & $0.471-2.066$ & 0.971 \\
\hline Hypertension & & & & 1.252 & $0.826-1.899$ & 0.290 \\
\hline Obesity & & & & 1.131 & $0.788-1.624$ & 0.503 \\
\hline Arrhythmia & & & & 1.342 & $0.828-2.175$ & 0.233 \\
\hline $\begin{array}{l}\text { Peripheral vascular } \\
\text { disease }\end{array}$ & & & & 1.606 & $0.771-3.347$ & 0.206 \\
\hline Ischemic Heart Disease & & & & 2.023 & $1.299-3.149$ & 0.002 \\
\hline Malignancy & & & & 3.071 & $2.018-4.672$ & $<0.001$ \\
\hline
\end{tabular}

Model (A) is based on a multivariable logistic regression adjusted for age, gender and ethnic/religious sector. Model (B) is based on multivariable logistic regression accounting for age, gender, ethnicity, and the assessed chronic conditions (COPD, asthma, hypertension, obesity, reported arrhythmia, peripheral vascular disease, ischemic heart disease, and malignancy) 
Figure 1: Cohort creation flowchart

$$
\begin{aligned}
& \text { 161,783 distinct patients tested for } \\
& \text { SARS-CoV-2 in Clalit Health Services, } \\
& \text { up to May 16, } 2020 \\
& -\quad 5,363 \text { positive } \\
& -\quad 156,147 \text { negative }
\end{aligned}
$$

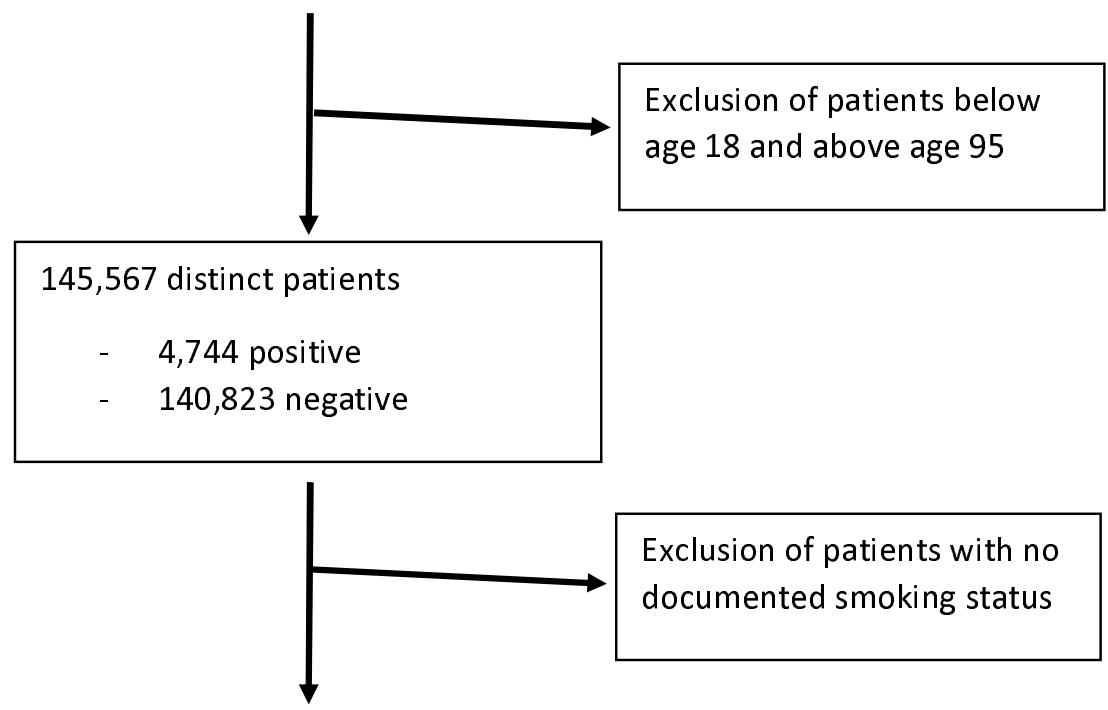

\section{Full cohort}

128,427 distinct patients

- $\quad 4,235$ positive

- $\quad 124,192$ negative

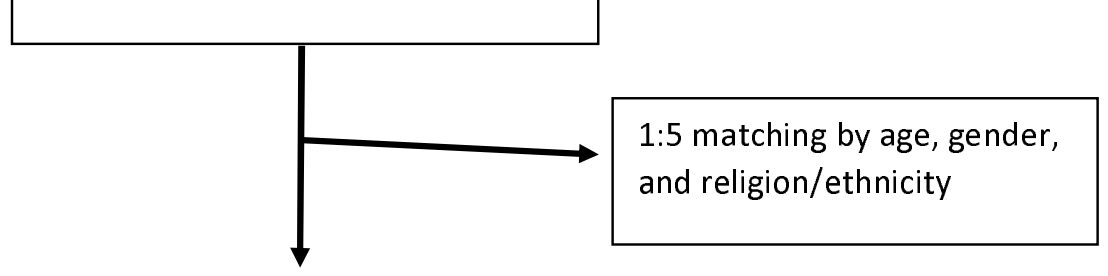

\section{Matched cohort}

24,906 distinct patients

- 4,151 positive

- 20,755 negative 